\title{
THE INTERPLAY BETWEEN PERFORMANCE BONDS AND THE PRINCIPLE OF INDEPENDENCE OF THE BANK'S COMMITMENT IN JORDAN
}

\author{
Emad Mohammed Al-Amaren; Che Thalbi Bt Md. Ismail; \\ Mohd Zakhiri bin Md. Nor \\ School of Law, College of Law, Government, and International Studies \\ University Utara Malaysia \\ Email: amareenroma1993@gmail.com; chet1048@uum.edu.my; \\ zakhiri@uum.edu.my
}

\begin{abstract}
As the wide range of international trade out-turn and diversity of the parties, causing banks have to create a new credit service, that is bank guarantees, to enhance the trust between the parties. By providing the security and ease, the beneficiary will obtain a certain amount of money from the bank and being independent from the other party. While the committed party provides insurance to the beneficiary as a guarantee for the implementation or good performance in accordance with agreed terms, in this situation, performance bonds are crucial to be considered as this tool has the principle of independence regarding the bank's commitment, as such, could clarify one party obligation to provide money, services or goods to another party. Taking performance bonds as solution whereby accompanied the Guaranty (Al Kafala) and subordination imposed by the legal system, the lacunae of legal rules which govern performance bonds has created difficulties and may lead Judges to create the new relevant law. This article is aimed at studying how the Jordanian Judiciary deals with performance bonds, since there is no previous legal rules governing such bank contract.
\end{abstract}

Keyword: Performance Bonds; the Principle of Independence; Bank >s Commitment, Jordanian Practice.

\section{INTRODUCTION}

Performance bond is a type of contract issued by a financial institution (B. Wu, 2017:3) which is considered one of the most important banking operations. It can be used either in domestic and global trade for buying and selling cargo. (Luhar, A. ,2014:19), as such, it is very much needed by traders and other economic segments of society. Whilst the legal nature of principle of independence in performance bonds is recognized, as it is subjected to banking norms, the absence of legislative rules governing relevant bank contract and due to similarity between performance bonds with other legal systems, this may lead to a status quo whereby the principle of independence could be implemented.

152 Yustisia Volume 8 Number 2 (May-August 2019)

The Interplay Between ...

(C)2019; This is an Open Acces Research distributed under the term of the Creative Commons Attribution Licencee (https://Creativecommons.org/licences/by/4.0), which permits unrestricted use, distribution, and reproduction in any medium, provided the original works is properly cited. 
In examining the legal nature of the principle of independence in the lacunae of legal rules, there are two highlighted points, namely the judicial authorities in interpreting the principle of independence and any possibility as recognized exception to the principle. In respect of this matter, this article provides two main discussion with Jordan practice as special reference. First, the method that used by Jordanian Judiciary regarding the principle of independence application. Second, the Islamic Sharia point of view in relation with performance bonds (the definition, importance, characteristics, implications and its exceptions).

The article is divided into four part namely : the first section will illustrate the historical background of the performance bonds. It elaborated the concept of performance bonds and provides information about the Islamic point of view to performance bonds. Second section explains show the Jordanian practice regarding performance bonds and the principle of independence. Finally, the last section will reveal the implications of the principle of independence on the bank's commitment and the exceptions to the principle of independence in Performance Bonds.

\section{RESEARCH RESULT AND DISCUSSION}

\section{A. Performance Bonds In International Regulation}

In international practices, the term "Performance Bonds" was first introduced into a set of international rules for the interpretation of trade terms established by the International Chamber of Commerce in 1953, known as the Codex of Incoterms. The International Chamber of Commerce issued the Uniform Rules for Demand Guarantees (URGD) No.758 in 2010-(last version)-. Article (2) provides a definition for Performance Bonds as follows: «With respect to the application of these rules, the guarantee on demand means any signed undertaking, however named or described, providing for payment on presentation of a complying demand. (Uniform Rules for Demand Guarantees (URGD) No.758 in 2010).

United Nations convention on independent guarantees and stand-by letters of credit defines Performance Bonds in article (2) as follow: "for the purposes of this convention, an undertaking is an independent commitment, known in international practice as an independent guarantee or as a stand-by letter of credit, given by a bank or other institution or person guarantor or issuer to pay to the beneficiary a certain or determinable amount upon simple demand or upon demand accompanied by other documents, in conformity with the terms and any documentary conditions of the undertaking, indicating, or from which it is to be inferred, that payment is due because of a default in the performance of an obligation, or because of another contingency, or for money borrowed or advanced, or on account of any mature indebtedness undertaken by the applicant 
or another person". (United Nations Convention on Independent Guarantees and Stand-By Letters of Credit, 1996).

\section{Defining The Concept}

The Performance Bond is defined as: a written undertaking issued by a bank at the request of one of it is clients in respect of a specific transaction. Accordingly, the bank pays to the interest of a third party called the beneficiary a specified amount of money, at the first request, whether justified or specified, or accompanied by the submission of specific documents mentioned in the text of the Performance Bonds, during a specified or unspecified period. and even if this is against the client's will. (Sulayman Ahmed Mohammad Al Qirim,2003:23).

The Performance Bonds includes three parties, the customer, who orders the issuance of the letter, the bank and the beneficiary. The client benefits from this process since he needs a cash insurance, otherwise his capital will be frozen for the benefit of the beneficiary. In the Performance Bonds, the beneficiary finds a serious and certain guarantee that is no less important than cash insurance because the bank usually enjoys a high reputation and has a considerable financial capacity. The bank issuing the Performance Bonds is benefiting from this process because it receives a commission and interest for the issuance of the letter. (Servet Armagan, 1998:156).

As currently considered as one of the most important forms of bank credit, performance bonds has its importance in economic life, especially in the field of government tenders. This is because most legislations require from people who want to deal with the government on a contract to provide a cash guarantee to show seriousness and to cover certain proportion of the value of the warranty. Its importance is also shown with respect to the customs deposit system, the temporary permit system, the transit goods system, and in the dispute with the tax authority about the value of the tax. (Mohamed Hassan Al-Jabr, 1997:322).

The bank receives a commission for the issuance of the letter, commensurate with the value of the contract and the duration of the guarantee and the type of guaranteed operation. In addition, the bank may retain the value of the cover of the Performance Bonds provided by the customer throughout the validity of the letter, and this increases the bank's deposit. As for the customer, the benefit of the Performance Bonds is great, as not freezing his capital and use it in some aspects of the most useful activity, and it encourages the client who does not have the costs of applying for contract to get into the contract, because he does not commit to provide cash directly when contracting. This means that the Performance Bonds opens the 
door for young business people and increases the quality of service through legitimate competition among them (Abdulrahman Al-Qorman, 2010:379). Thus, the Performance Bonds has great importance to all parties (client, bank, beneficiary).

As for the beneficiary, obtaining this letter from an accredited bank and pledging an independent undertaking is an important, specific and sufficient guarantee that is no less important than providing a monetary amount by the customer. (Aziz Al-Okaili, 2007:450). Bank credit operations are of the most important activities of banks. They assist in the economic and social development processes. These operations provide businessmen with the necessary financing to expand and develop local and international trade as well as the letter of credit which considered as the life blood of international commerce. (Alrabei, Ali Mahmoud Abdallah,2017:410)

\section{Islamic Law Perspective}

Performance Bonds in Islamic banks or "khitab - al-Daman" is a letter in which a bank guarantees debt or performance of someone against someone else that it shall be paid or performed and to pay in case of his failure and default. The banks issuing the letter is called the guarantor, the one who ask the bank to issue the letter is the Applicant of the issuing bank and the last person is the beneficiary, the guaranteed party in the guarantee contract. (Servet Armagan, 1998:155-156).

As for the Performance Bonds in Islamic law, this system has found a place within the framework of the Islamic Sharia. The bank guarantee letter includes a guaranty of money (Kafalt Almal(or agency) Wikala (according to the cover provided. It can be a guarantee of money )Kafalt Almal( because the bank is committed to the performance of a certain amount of money during a specified period. ) Omar Suleiman Mohammed Ramadan,2009:13). This can be found when the customer does not provide a cover for the Performance Bonds. It can also be an agency contract) Aquid Wikala), especially when the customer provides a total cover of the Performance Bonds. The Performance Bonds can be a composite contract (Aaqad Murkib) between the guarantee and the agency in the case of partial cover. The bank's commitment to the coated part is an agency (Wikala), and its commitment to the uncoated part is a guarantee (Kafala) (Ahmed Hassan,2008:68).

In the nature of the wages adjustment of the bank to issue the Performance Bonds, the Islamic banks take the concept of administrative expenses incurred by the bank in issuing the Performance Bonds, so as to depart from the jurisprudential rule according to which the contract of 
sponsorship is considered from the donation contracts, which prohibits the payment of fees, because taking fees makes the Performance Bonds as a loan that drags benefit, which is haram (not allowed) in Sharia. To avoid this, the scholars of Islamic law produced the "wage" as a substitute for the administrative expenses that the banks incur in issuing the letter. (Wahba alZuhaili,2008:52). As for the formation of the Performance Bonds in Islamic Sharia, it is the same as in other banks and does not differ, but only in the use of the word sponsorship or agency according to the cover provided. (Emad Amareen,2017:139).

\section{B. The Principle Of Independence In Jordanian Practice}

Performance Bonds is an undertaking to pay a monetary amount within certain limits and the base contract is considered as a guarantee created for its implementation but at the same time it is separated from it, and claims derived from it may not be invoked. (Abdullah: Ihab Mohamed Nour, 2009: 36). The Bank does not monitor the client>s performance of its obligations, nor undertakes to fulfill the obligations of the client in case the latter fails to do so. The bank does not repay the debt of the customer but pays the debt as being its own debt. (Awad Ali Jamal al-Din, 2000: 80).

The bank, due to its undertaking in the Performance Bonds, is committed as an original and does not monitor the customer's good performance of his obligation to the basis contract between him and the beneficiary (the original in the Performance Bonds), and the fulfillment of its commitments does not depend on an incident beyond it, nor on achieving a condition or the due date is achieved. Also, the execution is not related to an action that is attributed to the beneficiary of the Performance Bonds. Although, Performance Bonds is issued in implementation of the contract between the bank and its client, the bank>s relationship with the beneficiary (the guarantee is issued for his favor) is a separated relationship from the bank s relationship with the client. That is, this relationship is governed by the Performance Bonds alone and its terms shall determine the obligation of the bank and the conditions under which bank shall pay if the beneficiary requests the payment within the validity period of the Performance Bonds, and the conditions have been fulfilled and the documents specified in the Performance Bonds are submitted. (Awad Ali Jamal al-Din, 2000: 73)

The independence of the Bank>s commitment means its separation and independence from all interrelated relationships of the Performance Bonds except for the Bank>s relationship with the Beneficiary. (Radhia Amqran, 2014: 28) Due to the independence of the Bank>s obligation, there are no effects of the customer $\mathrm{S}$ 
defenses resulting from the contract of guarantee between the customer and the bank. If the customer>s will be flawed by a defect of satisfaction, it does not affect the bank>s commitment, nor does the termination of the contract affect it. The Bank s commitment remains in force despite the abolition of the contract. (Samiha al-Qiloubi, 1988: 446). This characteristic also means that the Bank>s obligation is independent of the base contract or the relationship between the customer and the beneficiary, since such contracts are final undertakings that are irrevocable and separate from the underlaying contracts. (Omar Suleiman Mohammed Ramadan,2009:235).

The second article of the Uniform Rules for Demand Guarantees (URGD) No.758 has stated: « A guarantee is by its nature independent of the underlying relationship and the application, and the guarantor is in no way concerned with or bound by such relationship. A reference in the guarantee to the underlying relationship for the purpose of identifying it does not change the independent nature of the guarantee. The undertaking of a guarantor to pay guarantee is not subject to claims or defenses arising from any relationship other than a relationship between the guarantor and the beneficiary" (Uniform Rules for Demand Guarantees (URGD) No.758 in 2010)

The Jordanian legislator did not address the definition of letter of guaranty. Although the letter of guaranty has not been mentioned by the Jordanian legislator, one can notice that the autonomy principle is in some way is referred in Article 118: "If a financial credit has been issued to guarantee a second party>s rights and the bank in its role authorized such a credit, withdrawal or amendment to this credit is no longer legal without authorization from the second party in question. In such a credit, the bank is obligated to execute the credit once the documents are submitted». (Jordanian Trade Law No. 12 of 1966.) While the term financial credits are surrounded by ambiguity as it is not clear what such a concept stands for. and what financial instruments it covers, it is still noteworthy that the legislaore has introduced the notion of the autonomy principle even if it is intended to be applied in a different context. (Alawamleh, Kamal Jamal Awad,2013:276).

The Jordanian Court of Cassation affirmed the independence of the Performance Bonds in several provisions, from which is «Where the letter of bank guarantee is a final pledge issued by the bank at the request of the client to pay cash to the beneficiary immediately after the request within a specified period, a commitment unrelated to the sponsor's commitment, since the Performance Bonds establishes a direct relationship between the bank and the beneficiary that is not related legally to the relationship between the guarantor and the bank or between the guarantor and the beneficiary of the Performance Bonds. 
Accordingly, the bank in the Performance Bonds complies with its sole will in a direct and unconditional obligation on condition and without verifying any incident outside the Performance Bonds. It is an obligation to pay the amount specified to the beneficiary upon his request, and this obligation is not connected to the obligation of his client or his subordinates, nor does depend on fulfilling any condition or element. This is because one of the main characteristics of the Performance Bonds is being independent from the original relationship that has been the reason for its existence. (Decision No. 2077/98, dated 14/4/1999, Qustas Journal of Human Rights).

\section{Legal Implications For The Bank}

The outcome or consequences of being involved in something according to the law can be resulted in legal implication. As a rule, a performance bond is considered in force until the stated discharge date which is usually either after practical completion of the works or after making good any defects. However, the bond cannot be withdrawn unless the client agrees to an earlier release date. The Bank shall not be allowed to pay by clearing to the beneficiary if there is a debt owed by the customer to the bank, because this relationship is separate in terms of its parties and independent in terms of its place. (Samiha al-Qiloubi, 1988: 447). The Performance Bonds itself is assumed as self-sufficiency. Thus, for whatsoever of it contains, the document of the Performance Bonds is sufficient to judge on its basis. The bank does not need to search and look in the basic contract to determine the right of the beneficiary to claim the value of the Performance Bonds. (Mahmoud al-Kilani, 2008: 343).

Discharging the ordered by the beneficiary does not affect the bank's obligation. The bank's obligation is to pay at the first request, and it cannot be changed. (Talal Ali Sulaiman Al-Shobaki, 2015: 58). Based on that, the Egyptian Court of Cassation decided that" the debtor of the bank must initiate the complaint to the judiciary if it is estimated that he is not owed to the beneficiary or that his indebtedness does not justify what the beneficiary of the bank has received. (Samiha al-Qiloubi, 1988: 446).

The Bank's obligation is not considered a subordinate obligation as in the case of a guarantee, but independent as in documentary credits. (Abdullah: Ihab Mohamed Nour, 2009: 36). To confirm this, the Standard Rules issued by the International Chamber of Commerce in article 2 states: «guarantees by nature are separate from the contract or contracts or conditions of tenders that are the basis for them.» (Standard Rules of the Paris International Chamber of Commerce for Performance Bonds payable on request - Handbook No. 458-1992). 


\section{Exceptions To The Principle Of Independence}

The jurisprudence confirmed on many occasions that the independence of the bank's commitment to the Performance Bonds is not absolute, but it is subject to exceptions, as in the state of fraud and apparent abuse of the beneficiary. The Bank's refusal to comply with the guarantee letter because of fraud is based on the rule that fraud corrupts everything and is met by good faith in transactions. Therefore, the Bank has the right to refuse a request for payment if it is fraudulent or abusive by the beneficiary. (Radhia Amqran, 2014: 108)

Fraud is defined as "the use of the guarantee by the beneficiary for the purpose of causing harm to the client with whom he contracted in a way which leads to the deviation of the mechanism of such bank guarantees at the purpose or target for which it is found, and contrary to the principle of good faith." (Omar Suleiman Mohammed Ramadan,2009:249).

In the definition of fraud that prevents the fulfillment of the Performance Bonds there are two points of view.

The first trend takes the broad sense of the concept of fraud that prevents fulfilment. Among those is the jurist "Stofleh". "The proponents of this trend are not limited to defining the concept of fraud by resorting to fraudulent methods but consider any request by the beneficiary to the value of the Performance Bonds in clear bad faith or a blatant abuse is a fraud even if this is not associated with fraudulent methods. (Talal Ali Sulaiman Al-Shobaki, 2015: 77).

The other approach believes that the fraud that prevents the fulfillment in the Performance Bonds is the fraud associated with fraudulent means, but not those accompanied with arbitrariness. Their explanation for the exclusion of the idea of arbitrariness is that this would take the Performance Bonds out of the principle of independence and leads to look in the base contract for the identification of rights. Dr. Ali Jamal al-Din Awad supports this view. (Awad Ali Jamal al-Din, 2000: 362).

The jurisprudence agreed on certain conditions in the fraud that prevents the fulfillment, including that the fraud must be constant and clear, supported by temporary evidence that does not accept discussion, in other words, the fraud must be clear and not be likely, because bad faith is not supposed. The second condition of fraud that prevents fulfillment is that fraud should be issued by a person to be invoked against, it must be issued by the beneficiary himself. (Awad Ali Jamal al-Din, 2000: 361-363).

Fraud destroys the principle of independence of the Performance Bonds and leads to the integration of all relationships, giving the bank the right to search in the base contract to ascertain the right of the beneficiary, and can abstain and adhere client's defenses. (Radhia Amqran, 2014: 1O8). 
The concept of fraud is like the apparent arbitrariness in that they both leave the same effect, namely, the bank's refusal to meet the value of the Performance Bonds. Arbitrariness unlike fraud does not require the use of fraudulent methods by the beneficiary, but merely the right to claim the value of the letter. (Radhia Amqran, 2014: 109).

The old-fashioned construction of contract has created more damage to the implementation of this tool. Possible disputes within the tripartite contract might occur in related to confusing interpretations of terminologies, unclear liabilities and obligations, potential misuse of authority and questionable rights in the contract. This situation may lead to parties unsuccessful in observing the fundamental principles and objective of the instrument, thus, the parties neglected the ideal surface guideline and definition provided by the banking system. Considering the one-sided interpretations of the contract, it remains to lacks in uniformity and inconsistency in the contents of guarantee/bond forms. Moreover, The courts remained resistant towards the subject but contribute to slight discrepancy manner in their decisions, probably due to the existing irregularity and the absence of uniformity in the contract itself. (A A Hassan and H Adnan, 2018).

\section{CLOSING}

\section{A. Conclusion}

Performance Bonds has a special nature that is different from other banking operations and is expressed as: an undertaking made by a bank to pay at the first request a certain amount of money in favor of a person called the beneficiary, based on an order from a person called the orderer within a specified period, related to a particular process or submitted of documents. Such undertaking shall be irrevocable from the moment of his arrival to the knowledge and acceptance of the beneficiary. The independence of the Bank's commitment means its separation and independence from all interrelated relationships of the Performance Bonds, except for the Bank's relationship with the Beneficiary. This characteristic also means that the Bank's obligation is independent of the base contract or the relationship between the customer and the beneficiary. Furthermore, there are no effects of the customer's defenses resulting from the contract of guarantee between the customer and the bank nor does the termination of the contract affect it. The independence of the bank's commitment to the Performance Bonds is not absolute, but it is subject to exceptions, as in the state of fraud and apparent abuse of the beneficiary. The Jordanian legislator did not address the letter of guaranty in the Jordanian Commercial law nor in the civil law. 
What is meant by the independence of bank's commitment (considering the economic function of the letter) is that the bank does not guarantee the client>s good performance of his obligations to the beneficiary. Firstly, he does not monitor the client>s performance of his obligations. Secondly it does not undertake to fulfill the obligations of the client in case he fails to fulfill them, and thirdly, it does not pay the debt of the client but rather pays the debt of its own, as an asset, not as a guarantor or agent. It can be said that the bank's commitment is a pure commitment and is not connected to the circumstances of the customer.» The independence of the bank $>\mathrm{s}$ commitment means its separation and independence from all interrelated relations of the Performance Bonds, except for the bank s relationship with the beneficiary

As for the Islamic Sharia point of view about the Performance Bonds, the Islamic Performance Bonds is different only in the name from the traditional commercial guarantee letter. We find that the Performance Bonds in the Islamic banks has the same characteristics, the purpose of which is to guarantee, but we find the difference in the name. Islamic banks deal with it by using the term money or agency guarantee, and use the term administrative expenses instead of using commission. In order to confirm the above, there is no difference between the Islamic Performance Bonds and the traditional guarantee letter except by name.

\section{B. Recomendation}

1. The need for the Jordanian legislator to intervene in issuing special provisions for banks letters of guarantee;

2. Through this study, the researcher wants the Jordanian legislator to adopt the provisions of the International Chamber of Commerce regarding the Performance Bonds because they represent an update evolving on the banking practice and custom on Performance Bonds.;

3. In the need to find a clear definition of fraud that prevents the bank from fulfilling his promise in the Performance Bonds, the researcher suggests leaving it to the discretion of the judge and the case. 


\section{BIBLIOGRAPHY:}

\section{Books:}

Al Amareen, Emad Mohammed. (2017). Performance Bonds in the Jordanian Court Decisions

Al-Jabr, Mohamed Hassan. (1997). Commercial Contracts and Banking Operations, Saudi Arabia. King Saud University: Scientific Publishing and Printing Press.

Al-Qarman, Abdul Rahman Al-Sayed. (2010). Commercial Contracts and Banking Operations. Saudi Arabia: Al-Shukri Library and Banking Practices. Master Thesis. Jordan: Yarmouk University.

Awad, Ali Jamal Aldeen. (2000). Khitabat Aldaman Almasrifi. Cairo - Egypt: Dar Al Nahhah Arabia.

Kilani, Mahmoud. (2008). Almawsueat altijariat walmasrifiat - eamaliat albunuk. A comparative study, Amman, Jordan: Culture House, 1st edition.

Omar, Suleiman Mohammed Ramadan. (2009). Alnizam alqanuniu likhitabat aldaman almasrifiat Egypt. Dar al-Fikr al-Jami`, 1st edition.

Oqaily, Aziz. (2007). Sharah alqanun altijariu aljuz' alththani al'awraq altijariat waeamaliat albunuk Amman - Jordan. Dar Al Thaqafa for Publishing and Distribution.

Qeliobi, Samiha. (1988). Al'usus alqanuniat lieamaliat albunuk. Cairo - Egypt, Arab: Renaissance Publishing House.

Radhia Amqran. (2014). Khitabat Aldaman Almasrifi WamawqifAlshryet Al'iislamiat Minha. PhD Thesis, Faculty of Law, University of Algeria, Algeria.

Servet Armagan. (1998). Performance Bondsin Islamic jurisprudence, Annales XXXII, N.48.

Shobaki, Talal Ali Suleiman. (2015). The effect of fraud in bank demand in the Performance Bonds. Amman, Jordan: Master thesis, Faculty of Law, Middle East University.

Sulayman ahmed Mohammad Al Qirim. (2003). Guarantee letter of Islamic banks. Nablus, Palestine: Master Thesis, Faculty of Graduate Studies, An-Najah National University.

Wahba al-Zuhaili, (2008). Alfiqat Al'aslamiu Wa'adlitat. Part 5, Damascus, Dar alFikr, edition 6. 


\section{Journals:}

Alawamleh, Kamal Jamal Awad. (2013). Documentary Credits and Independent Guarantees: A Critique of the 'Fraud Exception'Position. English and Jordanian Law.

Alrabei, Ali Mahmoud Abdallah. (2017). Perception of Jordanian Banks Employees on the Relationship between Accounting Information Quality (AIQ) and Documentary Credits. International Journal of Applied Business and Economic Research, Volume 15. Number 19.

Hassan: Ahmed. (2008). Altatbiqat Almueasirat Lilqard Aldhy Jara Manfaeat. Journal of Economic and Legal Sciences, Volume 24. First issue. Damascus University.

Hassan, A A and H Adnan. (2018). The problems and abuse of performance bond in the construction Industry, IOP Conf. Ser.: Earth Environ. Sci. 117012044.

Luhar, A. (2014). Letter of Credit, and bank guarantee-which is more cost effective in selected Indian. industries International Monthly Refereed Journal of Research in Management \& Technology. V3. Available online on www.abhinavjournal. $\underline{\text { com }}$

Saleh: Azad Shakur. (2013). Fraud in Documentary Credits and its Impact on the Bank's Commitment, Journal of the Faculty of Law for Political and Legal Sciences, University of Kirkuk, Volume 2, Issue 4.

$\mathrm{Wu},(2017)$. Asset securitization and rate of return: A study on letters of guarantee, Physica. http://dx.doi.org/10.1016/j.physa.2017.08.143.

\section{Legal Documents:}

Jordanian Trade Law Number 12 of 1966.

United Nations Convention on Independent Guarantees and Stand-By Letters of Credit, 1996

Uniform Rules for Demand Guarantees (URGD) Number 758 of 2010 